\title{
Effect of different postnatal care practices on serum gamma globulin concentrations in neonatal foals
}

\author{
Lisa Tscheschlok', Judith Howard² and Monica Venner ${ }^{l}$ \\ 1 Equine Veterinary Clinic Destedt, Destedt, Germany \\ ${ }^{2}$ Clinical Diagnostic Laboratory, Department of Clinical Veterinary Medicine, Vetsuisse Faculty, University of Bern, Switzerland
}

\begin{abstract}
Summary: The aim of the present study was to evaluate failure of transfer of passive immunity (FTPI), estimated using electrophoretic gamma globulin concentrations (EGG), during the first 24 hours of life in neonatal foals given either intensive postnatal assistance to nurse or no assistance for the first twelve hours postnatum. Sixty warmblood foals from the same breeding farm were included in this prospective study. Of these, 40 foals (Group 1) were assisted to stand after one hour and nurse after two hours postnatum. They received colostrum by bottle hourly from two hours postnatum until they nursed unaided, as well as by bottle or nasogastric tube after eight hours postnatum if their general condition declined. A further 20 foals (Group 2) received no initial assistance but were given colostrum by bottle or nasogastric tube twelve hours postnatum if they had not nursed or if their general condition declined. A serum protein electrophoresis was performed from samples collected 6, 8, 10, 12, 18 and 24 hours after birth in each foal. In Group 1, 16/40 foals nursed unaided within two hours postnatum, 16/40 foals were assisted to the dam's udder, and 8/40 foals received colostrum by bottle. The median time from birth to the first unassisted intake of colostrum was 141 minutes and 149 minutes in Groups 1 and 2, respectively. The median EGG concentration was lowest at 6 hours postnatum in both groups. At 10 hours postnatum, both groups achieved a median EGG above $8 \mathrm{~g} / \mathrm{L}$. The highest median EGG concentration was reached at 12 hours in both groups, after which no significant change in EGG concentrations was observed. No significant difference in EGG concentrations was found between the groups. Moreover, no difference in the proportion of foals with FTPI (defined as EGG $<8 \mathrm{~g} / \mathrm{L}$ at 24 hours postnatum) was found between the groups. Findings of the present study suggest that EGG concentrations and FTPI are not significantly affected by the postnatal care practices used in this breeding farm. Further investigations are required to evaluate methods of postnatal care that may considerably impact FTPI in neonatal foals.
\end{abstract}

Keywords: foal, postnatal care, lgG, gamma globulins, electrophoresis, failure of transfer of passive immunity

Citation: Tscheschlok L., Howard J., Venner M. (2016) Effect of different postnatal care practices on serum gamma globulin concentrations in neonatal foals. Pferdeheilkunde 32, 616-622

Correspondence: PD, Dr. Monica Venner, PhD, Equine Veterinary Clinic, Trift 4,38162 Destedt, Germany; e-mail: mvenner@gmx.de

\section{Introduction}

Diaplacental transfer of immunoglobulins to the equine fetus is negligible, resulting in minimal serum immunoglobulin $G$ ( $\lg G)$ concentrations in neonatal foals immediately after birth (Schneider and Szathmary 1941, Jeffcott 1974a, Erhard et al. 2001). Equine neonates therefore rely on passive transfer of IgG via colostrum intake for humoral immunity to reduce the risk of infectious diseases in the first weeks of life (Jeffcott 1974b, McGuire et al. 1977, Robinson et al. 1993, Raidal 1996, Holznagel et al. 2003, Thein et al. 2005, Liepman et al. 2015). Adequate serum $\lg G$ concentrations in foals are generally defined as $\geq 8 \mathrm{~g} / \mathrm{L}$ (Koterba et al. 1985). Inadequate serum concentrations of $\lg G$ are considered as failure of transfer of passive immunity (FTPI), whereby concentrations of $<4 \mathrm{~g} / \mathrm{L}$ are considered as complete FTPI and those of $4-8 \mathrm{~g} / \mathrm{L}$ as partial FTPI (Ty/er-McGowan et al. 1997).

Newborn calves also require intake of colostral lgG for humoral immunity during the first few weeks of life (Stott et al. 1979a, Robison et al. 1988). Studies in calves indicate that quantity and quality of colostrum as well as time point and method for administering colostrum are all important factors preventing FTPI (Patel et al. 2014). Recommendations for postnatal care in calves are based on findings of a number of studies and include oral intake of at least $3 \mathrm{~L}$ of colostrum with $\lg G$ concentrations of at least $50 \mathrm{~g} / \mathrm{L}$ administered by bottle or esophageal tube immediately after birth (Stott et al. 1979b, Besser et al. 1991, Chigerwe et al. 2009, Godden et al. 2009). In contrast, very few studies have been carried out to validate recommendations for postnatal care in foals. Currently, intake of colostrum within two hours postnatum is generally recommended (Massey et al. 1991), given the progressive decline in the capacity of the intestinal mucosa to resorb IgGs (Jeffcott 1971, 1972, Raidal et al. 2000, Erhard et al. 2001). A concentration of at least $30 \mathrm{~g} / \mathrm{L}$ colostral lgG and an intake of at least $1.5 \mathrm{~L}$ colostrum are considered necessary to ensure a minimal protective humoral immunity in foals with a serum $\lg G$ concentration of at least $4 \mathrm{~g} / \mathrm{L}$ (LeBlanc et al. 1986, Thein et al. 1989, Massey et al. 1991). Mean initial colostral lgG concentrations in dams are approximately $55 \mathrm{~g} / \mathrm{L}$ (Erhard et al. 2001), although one study reported concentrations up to $118 \mathrm{~g} / \mathrm{L}$ (Warko and Bostedt 1993). However, $\lg G$ concentrations in dam's milk decline rapidly once a foal is nursing to only around $20 \%$ of initial concentrations by 6-12 hours postpartum (Erhard et al. 2001, Venner et al. 2008).

Previous studies showed that serum IgG concentrations in suckling foals peak at 12 to 18 hours postnatum (Massey et al. 1991, Warko and Bostedt 1993, Erhard et al. 2001). Although final assessment of FTPI is recommended at 24 hours postnatum, measurement of foal $\mathrm{lg} G$ concentrations are generally recommended at 8 to 12 hours postnatum so that oral supplementation may still be possible (Massey et al. 1991). However, to the authors knowledge very few studies aimed to evaluate the effect on serum lgGs in foals given ear- 
ly intensive assistance to feed compared to foals left to nurse at the dam's udder unassisted or the effects of early $(2-8$ hours postnatum) compared to late ( $8-12$ hours postnatum) oral colostrum supplementation (Jeffcott 1974b).

The aim of the present study was to evaluate serum $\lg G$ concentrations during the first 24 hours of life in neonatal foals subjected to an early and late intervention scheme using the electrophoretic gamma globulin fraction (EGG) as an estimate of lgG concentrations (Tscheschlok et al. 2016).

\section{Materials and methods}

Study population

Sixty warmblood foals (37 colts and 23 fillies) born in 2013 were included in the study. All foals were born in individual boxes in the same German breeding farm in which foaling was monitored by experienced farm staff.

Foals were included in the study if they were born after 310 to 350 days of gestation without dystocia, and showed an APGAR score of at least 4, which indicates a vital foal immediately after birth (Madigan 1990) with no malformations, severe limb deformities or life-threatening conditions. Foals were excluded if placentitis or illness of the mare was noted, the dam's colostral lgG concentration measured immeditely postpartum was below $29 \mathrm{~g} / \mathrm{L}$, or if the white blood cell count of the foal was below 2.0 or above $18.0 \times 10^{3} / \mu$ l at 8 hours postnatum.

\section{Study design}

The study was performed as a prospective investigation. Foals were divided into two groups according to a pre-assigned continuous order, in which the first two foals born were assigned to Group 1, and every third foal was assigned to Group 2.

Group 1 included 40 foals that were assisted to stand after one hour and to nurse after two hours if they had not already done so. Foals failing to nurse were administered a minimum of $200 \mathrm{ml}$ of their mother's colostrum by bottle every hour until they nursed unaided. After eight hours postnatum, foals were fed with a minimum of $200 \mathrm{ml}$ of foreign colostrum (frozen colostrum from other mares of the same farm) by bottle or nasogastric tube if their clinical condition declined, which was determined by weakness or reluctance to nurse or stand. Group 2 included 20 foals that received no special care other than supplementation with a minimum of $200 \mathrm{ml}$ foreign colostrum by bottle or nasogastric tube after twelve hours postnatum if they had not nursed or showed clinical decline as described above. Colostrum was administered by nasogastric tube only if foals refused or were too weak to accept bottle feeding.

\section{Blood sampling}

Venous blood was collected from each foal at 6, 8, 10, 12, 18 and 24 hours after birth. Blood samples were allowed to clot at room temperature for 20 minutes and were then stored at $4{ }^{\circ} \mathrm{C}$ overnight. The following day, samples were centrifu- ged for 10 minutes at $1520 \mathrm{~g}$ and serum was separated into aliquots of $1.5 \mathrm{ml}$, which were stored at $-20^{\circ} \mathrm{C}$ pending electrophoresis (performed within 6 months of sampling). In addition, an EDTA-anticoagulated blood sample was obtained at 8 hours postnatum to determine the white blood cell count using an automated haematology analyser ${ }^{a}$.

\section{Serum electrophoresis}

Serum electrophoresis was performed on agarose gels using a semi-automated method $^{b}$, according to the procedures described by the manufacturer. The electrophoresis gels were scanned by a densitometer ${ }^{c}$ and electrophoretic curves were evaluated using commercial software ${ }^{d}$. The serum proteins were separated into 6 fractions: albumin, alpha-1, alpha-2, beta-1, beta-2 and gamma. The electrophoretic gamma globulin concentration (EGG) was calculated based on the gamma globulin fraction and total protein concentrations, measured using a biochemistry analyser ${ }^{e}$ and commercial biuret reagent ${ }^{\dagger}$.

\section{Additional data collection}

Data collection included the age of the dam and duration of gestation. Colostrum quality was measured immediately postpartum using a modified sugar refractometer ${ }^{g}$. The refractive index (Brix\%) was used to estimate lgG concentrations using the formula, Brix $\%=0.2514 \mathrm{lgG}+11.17$ (Venner et al. 2008). Further data collected included foal gender, time from birth to first intake of colostrum and to first unassisted intake of colostrum.

\section{Statistical analysis}

Statistical analyses were performed using commercial software (MedCalc 13.3. $0^{\mathrm{h}}$ ). Normality was assessed by evaluating Q-Q plots and using the D Agostino-Pearson test. Comparison between the groups for continuous data was assessed using independent samples t-tests or Mann-Whitney tests. Comparison between groups for categorical data was assessed using Fisher s exact test. Differences in EGG concentrations between the groups of foals and within each group of foals at different time points were analysed using repeated measures ANOVA. Post-hoc pair-wise comparisons were analysed using Bonferroni correction. Significance was set at $p<0.05$ throughout.

\section{Results}

\section{Baseline values}

No significant difference was found between the groups for age of dams, mean duration of gestation, colostrum quality or the proportion of male and female foals (Table 1).

In Group 1, 16/40 foals nursed unaided, 16/40 were assisted to the dam's udder and $8 / 40$ received colostrum by bottle (median, $250 \mathrm{ml}$ ). The median time from birth to the first intake of colostrum was 117 minutes (Table 1). The median 
time to the first unassisted intake of colostrum was 149 minutes in Group 1 and 141 minutes in Group 2 (Table 1). The time to first intake of colostrum was significantly shorter in Group 1 than in Group 2 foals $(p=0.002)$, but no difference was found between the groups for the time to first unassisted intake of colostrum $(p=0.549)$.

Two foals in each group were given supplementation with foreign colostrum after eight hours and twelve hours, respectively. This was administered at 8.9 hours postnatum by nasogastric tube in one foal and at 9 hours by bottle in another foal in Group 1, and at 13.7 hours by nasogastric tube and 15 hours by bottle in one foal, and 13.8 and 16 hours by nasogastric tube in another foal in Group 2. In total, 25/40 foals in Group 1 were given some kind of assistance (placed at the udder, colostrum by bottle or nasogastric tube) and 2/20 of foals in Group 2 were given assistance (colostrum by bottle or nasogastric tube).

\section{Concentration of electrophoretic gamma globulins (EGG)}

In 360 serum samples (6 samples in each of 60 foals), the median concentration of EGG was $9 \mathrm{~g} / \mathrm{L}$ (range, $0-24 \mathrm{~g} / \mathrm{L}$ ). No difference in EGG concentrations was found between the groups (repeated measures ANOVA, $p=0.153$ ) but a significant difference was found between time points $(p<0.001)$ and no interaction between groups and time points was found $(p=0.765)$. The lowest median EGG concentrations were measured at 6 hours in both groups (Table 2). At 10 hours postnatum, both groups achieved a median EGG concentration of $>8 \mathrm{~g} / \mathrm{L}$ (Table 2). The highest median concentrations were rea- ched by 12 hours, after which no significant change in EGG concentrations was found in either group (Table 2, Fig. 1).

\section{Failure of transfer of passive immunity (FTPI)}

Concentrations of EGG $<8 \mathrm{~g} / \mathrm{L}$ at 24 hours were observed in $17 / 60(28.3 \%)$ foals, of which 11/40 were in Group 1 and $6 / 20$ were in Group 2. The proportion of foals with FTPI did not differ between the groups $(p=1.000)$.

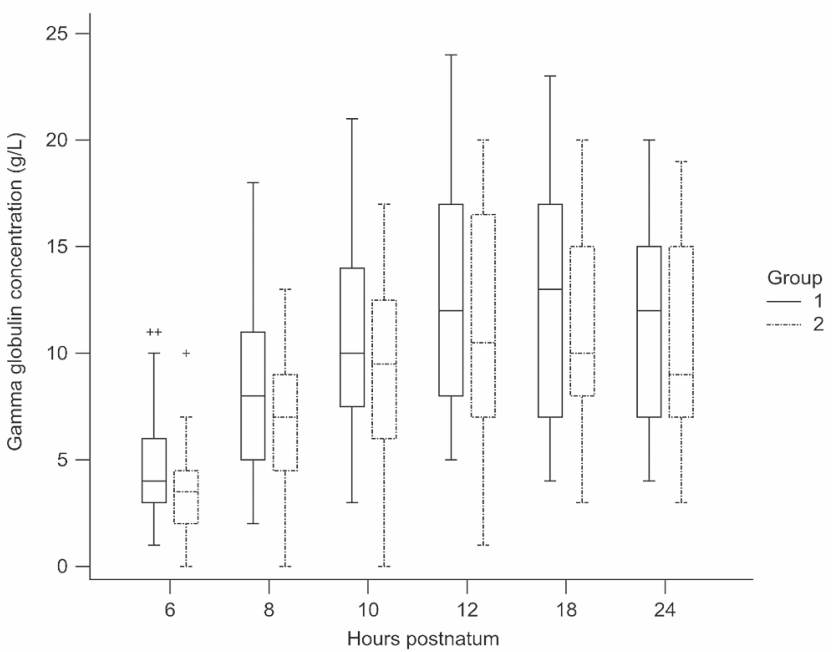

Fig. 1 Boxplots showing electrophoretic gamma globulin concentrations at the different time points in both groups of foals. Der Box-Whisker-Plot zeigt die Gammaglobulin-Konzentrationen zu den einzelnen Zeitpunkten in beiden Fohlengruppen.

\begin{tabular}{|c|c|c|c|c|}
\hline omparison between foal groups for b & All foals & Group 1 & Group 2 & P-value \\
\hline Number of foals & 60 & 40 & 20 & \\
\hline Gender of foals ( $M$, male; $F$, female) & $37 \mathrm{M}, 23 \mathrm{~F}$ & $24 \mathrm{M}, 16 \mathrm{~F}$ & $13 \mathrm{M}, 7 \mathrm{~F}$ & 0.783 \\
\hline Age of mares (years; mean $\pm S D$ ) & $10.2 \pm 4.8$ & $9.8 \pm 4.7$ & $10.9 \pm 5.0$ & 0.414 \\
\hline Duration of gestation (days; mean $\pm S D$ ) & $338 \pm 6$ & $338 \pm 6$ & $338 \pm 6$ & 0.691 \\
\hline Colostrum quality [g/L; median (range)] & $66.9(29.6-133.8)$ & $70.5(39.5-133.8)$ & $60.6(29.6-86.4)$ & 0.052 \\
\hline $\begin{array}{l}\text { Time to first colostrum intake [minutes; median } \\
\text { (range); interquartile range] }\end{array}$ & $\begin{array}{l}121(45-465) \\
98.5-140.5\end{array}$ & $\begin{array}{c}117(45-155) \\
94-131.5\end{array}$ & $\begin{array}{c}141(84-465) \\
112-207\end{array}$ & 0.002 \\
\hline $\begin{array}{l}\text { Time to first unassisted colostrum intake [minutes; } \\
\text { median (range); Interquartile range] }\end{array}$ & $\begin{array}{l}146(45-484) \\
106.5-204.5\end{array}$ & $\begin{array}{c}149(45-484) \\
94.5-204.5\end{array}$ & $\begin{array}{l}141(84-465) \\
112-207\end{array}$ & 0.549 \\
\hline
\end{tabular}

Table 2 Electrophoretic gamma globulin concentrations during the first 24 hours postnatum in the two groups of foals | GammaglobulinKonzentrationen in den ersten 24 Stunden post natum in beiden Fohlengruppen

\begin{tabular}{|c|c|c|c|c|c|c|c|}
\hline \multirow{2}{*}{ Group } & \multirow{2}{*}{$\begin{array}{l}\text { Gammaglobulin } \\
\text { concentrations }\end{array}$} & \multicolumn{6}{|c|}{ Time point postnatum (hours) } \\
\hline & & 6 & 8 & 10 & 12 & 18 & 24 \\
\hline \multirow{4}{*}{$\begin{array}{l}\text { Group } 1 \\
(\mathrm{~N}=40)\end{array}$} & Mean $(g / L)$ & $4.8^{a}$ & $8.2^{b}$ & $10.8^{c}$ & $12.5^{\mathrm{d}, \mathrm{e}}$ & $12.7^{d, f}$ & $11.9^{c, e, f}$ \\
\hline & $\mathrm{SD}(\mathrm{g} / \mathrm{L})$ & 2.7 & 4.1 & 4.9 & 5.2 & 5.3 & 4.7 \\
\hline & Median (g/L) & 4.0 & 8.0 & 10.0 & 12.0 & 13.0 & 12.0 \\
\hline & Range (g/L) & $1.0-11.0$ & $2.0-18.0$ & $3.0-21.0$ & $5.0-24.0$ & $4.0-23.0$ & $4.0-20.0$ \\
\hline \multirow{4}{*}{$\begin{array}{l}\text { Group } 2 \\
(\mathrm{~N}=20)\end{array}$} & Mean & $3.6^{a}$ & $6.7^{b}$ & $8.8^{c}$ & $10.8^{d, e}$ & $10.6^{d, f}$ & $10.3^{e, f}$ \\
\hline & SD & 2.5 & 3.8 & 5.0 & 6.2 & 5.0 & 4.8 \\
\hline & Median & 3.5 & 7.0 & 9.5 & 10.5 & 10.0 & 9.0 \\
\hline & Range (g/L) & $0.0-10.0$ & $0.0-13.0$ & $0.0-17.0$ & 1.0-20.0 & $3.0-20.0$ & $3.0-19.0$ \\
\hline
\end{tabular}

Within each group, different superscript letters represent a significant difference in means $(p<0.05)$ 


\section{Discussion}

In this study, EGGs were measured at various time points during the first 24 hours of foals given intensive postnatal assistance or no assistance to nurse for the first twelve hours postnatum. Studies in cattle have shown a higher rate of FTPI in calves allowed to nurse unassisted compared to those given colostrum by bottle or feeding tube (Besser et al. 1991, Beam et al. 2009), but studies evaluating the effects of assisted compared to unassisted colostrum intake in foals are lakking. In the present study, foals were only given colostrum by bottle or tube if they did not nurse unassisted to avert interfering with the dam-foal bond. As a result, many foals in Group 1 received, except a initial help to find the udder, less assistance than those in Group 2, which may have diminished potential differences in serum EGGs between the groups.

The postnatal care of Group 1 foals (help on standing after one hour and assisted colostrum intake after two hours) was based on previous recommendations (Massey et al. 1991, Pierce 2003). Moreover, previous studies indicate improve serum lgG concentrations in calves given assistance to suckle (Edwards et al. 1982). Foals given colostrum by bottle or tube were given at least $200 \mathrm{ml}$ in hourly intervals, based on previous recommendations (Jeffcott 1974a, LeBlanc et al. 1986, Massey et al. 1991).

Markedly depressed foals or those with deformity, foals from mares with inadequate colostrum quality or those having suffered dystocia were excluded as withholding assistance for such foals in Group 2 might have endangered them. Moreover, Group 2 foals were given colostrum after twelve hours if their condition was deemed poor as previous studies have shown increased mortality in calves from which colostrum was withheld for over twelve hours (Stott et al. 1979a).

Baseline values observed in the two groups of foals were comparable. Although the time between birth and first intake of colostrum was significantly lower in Group 1 than in Group 2 due to the assistance in colostrum intake in group 1 , this assistance for nursing in Group 1 did not result in either a more rapid or a delayed time to unassisted nursing. The time to unassisted nursing (149 and 141 minutes in Groups 1 and 2, respectively) was somewhat longer than the 91 minutes observed in 17 foals in a previous report (Massey et al. 1991). However, findings of the present study are consistent with the general consensus that foals nurse independently within one to three hours postnatum (LeBlanc 2001).

Concentrations of EGGs were used to assess immunoglobulin concentrations despite the fact that this method does not directly measure lgG concentrations. However, a previous study has shown good agreement between EGG and IgG by radial immunodiffusion (Tscheschlok et al. 2016). No significant difference was found in EGG concentrations between the groups despite the different postnatal care given. In fact, individual foals in both groups had concentrations considered as FTPI (EGG $<8 \mathrm{~g} / \mathrm{L}$ ) even at 24 hours postnatum. This suggests that the early and intensive care given in this study had little influence on colostral antibody transfer in newborn foals. Nevertheless, as only ostensibly normal foals from mares with adequate colostral lgG concentrations were included, further investigations on larger numbers of animals are necessary before recommendations can be made. Despite findings of this study, assistance to nurse and ingest colostrum is likely necessary for weakened foals (Ousey 1997).

Further studies are necessary to clarify which management strategies may result in optimal passive transfer of immunity in foals. Higher serum $\lg G$ concentrations were achieved in calves given greater quantities of colostrum (Stott et al. 1979b, Chigerwe et al. 2009, Godden et al. 2009) but foals generally do not ingest more than around $250 \mathrm{ml}$ per bottle feed. Whether a higher feeding frequency would lead to greater overall volumes ingested is unclear. The precise optimal time of initial colostrum ingestion in foals is unclear. Calves ingesting colostrum immediately after birth were found to have higher $\lg G$ concentrations that those ingesting colostrum at a later time (Stott et al. 1979b). As the suckle reflex is generally present in foals within 30 minutes after birth (Curcio and Nogueira 2012), assisted colostrum intake much earlier than 2 hours postnatum is theoretically possible.

In the present study, mean postnatum serum EGG concentrations $(8.2 \mathrm{~g} / \mathrm{L}$ and $6.7 \mathrm{~g} / \mathrm{L}$ at 8 hours, and $12.7 \mathrm{~g} / \mathrm{L}$ and $10.6 \mathrm{~g} / \mathrm{L}$ at 18 hours in Groups 1 and 2, respectively) were lower than those previously measured using ELISA techniques $(9.6 \mathrm{~g} / \mathrm{L}$ at $5-8$ hours in 13 foals and $15.8 \mathrm{~g} / \mathrm{L}$ at $13-$ 16 hours postnatum in 18 foals) (Erhard et al. 2001). Likewise, higher concentrations were measured by radial immunodiffusion in 16 foals in a previous study (Warko and Bostedt 1993). These differences are likely, at least in part, due to the different methods used to measure immunoglobulin, as well as differences between the various cohorts, colostrum quality, and varying time points and quantities of ingested colostrum.

EGG concentrations in the present study increased from 6 to 12 hours postnatum, after which no significant changes were observed up to 24 hours. This is similar to the previously reported maximum lgG levels at 12 hours in 17 foals (Massey et al. 1991). Foals in the present study had a mean and median EGG concentration of $\geq 8 \mathrm{~g} / \mathrm{L}$ at 10 hours postnatum in both groups, suggesting adequate passive transfer of immunoglobulins (Koterba et al. 1985). Evaluation of EGG concentrations between 10 -to 12 hours postnatum appears to be adequate to assess FPTI in foals subjected to the management procedures used in this study. Previous recommendations included assessment of $\lg G$ concentrations at 8 to 12 hours postnatum (Massey et al. 1991) but most foals in Group 2 in the present study would have fallen short of the desired $8 \mathrm{~g} / \mathrm{L}$ at 8 hours postnatum.

In conclusion, data in this study revealed no association between the two types of postnatal care practice and EGG concentrations in foals during the first 24 hours of life. Further studies with larger numbers of foals, and mares of varying colostrum quality are necessary.

\section{Acknowledgements}

The authors thank P. S. Pferdehaltung GmbH, Neustadt-Glewe, Germany for funding the study and Vet Med Labor $\mathrm{GmbH}$, Idexx Laboratories, Ludwigsburg, Germany for the determination of EGG by serum electrophoresis. 


\section{Manufacturer's addresses}

a Sysmex KX-21N, Sysmex Deutschland GmbH, Norderstedt, Germany

b Sebia Hydrasys ${ }^{\circledR} 2$, Sebia, Lisses, France

c Gelscan ${ }^{\mathrm{TM}}$, Sebia, Lisses, France

d Phoresis-Software, Sebia, Lisses, France

e Clinical Chemistry System AU5800, Beckman Coulter $\mathrm{GmbH}$, Krefeld, Germany

f Total Protein Reagent, OSR6232, Beckman Coulter $\mathrm{GmbH}$, Krefeld, Germany

9 Digital Hand-held 'Pocket' Refractometer PAL-1, Fa. ATAGO CO., LTD, Tokyo, Japan

h MedCalc Software, Version 13.3.0, Ostend, Belgium

\section{References}

Beam A. L., Lombard J. E., Kopral C. A., Garber L. P., Winter A. L., Hikks J. A., Schlater J. L. (2009) Prevalence of failure of passive transfer of immunity in newborn heifer calves and associated management practices on US dairy operations. J. Dairy Sci. 92, 3973-3980

Besser T. E., Gay C. C., Pritchett L. (1991) Comparison of three methods of feeding colostrum to dairy calves. J. Am. Vet. Med. Assoc. 198, 419-422

Chigerwe M., Tyler J. W., Summers M. K., Middleton J. R., Schultz L. G., Nagy D. W. (2009) Evaluation of factors affecting serum IgG concentrations in bottle-fed calves. J. Am. Vet. Med. Assoc. 234, 785-789

Curcio B. R., Nogueira C. E. W. (2012) Newborn adaptions and healthcare throughout the first age of the foal. Anim. Reprod. 9, 182-187

Edwards S. A., Broom D. M., Collis S. C. (1982) Factors affecting levels of passive immunity in dairy calves. Br. Vet. J. 138, 233-240

Erhard M. H., Luft C., Remler H. P., Stangassinger M. (2001) Assessment of colostral transfer and systemic availability of immunoglobulin $G$ in new-born foals using a newly developed enzyme-linked immunosorbent assay (ELISA) system. J. Anim. Physiol. Anim. Nutr. 85, 164-173

Godden S. M., Haines D. M., Konkol K., Peterson J. (2009) Improving passive transfer of immunoglobulins in calves. II: Interaction between feeding method and volume of colostrum fed. J. Dairy Sci. 92, 1758-1764

Holznagel D. L., Hussey S., Mihalyi J. E., Wilson W. D., Lunn D. P. (2003) Onset of immunoglobulin production in foals. Equine Vet. J. $35,620-622$

Jeffcott L. B. (1971) Duration of permeability of the intestine to macromolecules in the newly-born foal. Vet. Rec. 88, 340-341

Jeffcott L. B. (1972) Passive immunity and its transfer with special reference to the horse. Biol. Rev. 47, 439-464

Jeffcott L. B. (1974a) Some practical aspects of the transfer of passive immunity to newborn foals. Equine Vet. J. 6, 109-115

Jeffcott L. B. (1974b) Studies on passive immunity in the foal: 1. $\gamma$-Globulin and antibody variations associated with the maternal transfer of immunity and the onset of active immunity. J. Comp. Pathol. 84, 93-101

Koterba A. M., Brewer B., Drummond W. H. (1985) Prevention and control of infection. Vet. Clin. North Am. Equine Pract. 1, 41-50

LeBlanc M. M. (2001) Update on passive transfer of immunoglobulins in the foal. Pferdeheilkd. 17, 662-665

LeBlanc M. M., McLaurin B. I., Boswell R. (1986) Relationships among serum immunoglobulin concentration in foals, colostral specific gravity, and colostral immunoglobulin concentration. J. Am. Vet. Med. Assoc. 189, 57-60

Liepman R. S., Dembek K. A., Slovis N. M., Reed S. M., Toribio R. E. (2015) Validation of $\lg G$ cut-off values and their association with survival in neonatal foals. Equine Vet. J. 47, 526-530

Madigan J. (1990) Management of the newborn foal. Proc. 40(th) Annu. Conv. Am. Assoc. Equine Practnrs., 99-116
Massey R. E., LeBlanc M. M., Klapstein E. F. (1991) Colostrum feeding of foals and colostrum banking. Proc. 37(th) Annu. Conv. Am. Assoc. Equine Practnrs., 1-8

McGuire T. C., Crawford T. B., Hallowell A. L., Macomber L. E. (1977) Failure of colostral immunoglobulin transfer as an explanation for most infections and deaths of neonatal foals. J. Am. Vet. Med. Assoc. 170, 1302-1304

Ousey J. C. (1997) Thermoregulation and the energy requirement of the newborn foal, with reference to prematurity. Equine Vet. J. 29, 104-108

Patel S., Gibbons J., Wathes D. C. (2014) Ensuring optimal colostrum transfer to newborn dairy calves. Cattle practice 22, 95-104

Pierce S. W. (2003) Foal care from birth to 30 days: A practitioner $s$ perspective. Proc. 49(th) Annu. Conv. Am. Assoc. Equine Practnrs., 13-21

Raidal S. L. (1996) The incidence and consequences of failure of passive transfer of immunity on a Thoroughbred breeding farm. Aust. Vet. J. 73, 201-206

Raidal S. L., McTaggart C., Yovich J. V., Penhale J. (2000) Effect of withholding macromolecules on the duration of intestinal permeability to colostral lgG in foals. Proc. Annu. Conv. Am. Assoc. Equine Practnrs., 260-263

Robinson J. A., Allen G. K., Green E. M., Fales W. H., Loch W. E., Wilkerson C. G. (1993) A prospective study of septicaemia in colostrum-deprived foals. Equine Vet. J. 25, 214-219

Robison J. D., Stott G. H., Denise S. K. (1988) Effects of passive immunity on growth and survival in the dairy heifer. J. Dairy Sci. 71, 1283-1287

Schneider L., Szathmary J. (1941) Über die Herkunft der Immunität der neugeborenen Ferkel und Fohlen. Z. Immunitätsforsch. exp. Therapie 99, 275-281

Stott G. H., Marx D. B., Menefee B. E., Nightengale G. T. (1979a) Colostral immunoglobulin transfer in calves I. Period of absorption. J. Dairy Sci. 62, 1632-1638

Stott G. H., Marx D. B., Menefee B. E., Nightengale G. T. (1979b) Colostral immunoglobulin transfer in calves. III. Amount of absorption. J. Dairy Sci. 62, 1902-1907

Thein P., Essich G., Grunmach J., Abar B. (1989) Grundlagen und Kontrolle des Immunstatus beim Saugfohlen. Prakt. Tierarzt, 1 1, 15-28

Thein P., Essich G., Röhm A. (2005) Fohlenerkrankungen und Fohlenverluste - Ein Beitrag zur Ursache von Aborten im Zeitraum von 1972 bis 2002 im Haupt- und Landgestüt Marbach an der Lauter. Tierärzłl. Umsch. 60, 115-127

Tscheschlok L., Venner M., Howard J. (2016) Comparison of lgG concentrations by radial immunodiffusion, electrophoretic gamma globulin concentrations and total globulins in neonatal foals. Equine Vet. J. doi: 10.1111 /evj.12575

Tyler-McGowan C. M., Hodgson J. L., Hodgson D. R. (1997) Failure of passive transfer in foals: incidence and outcome on four studs in New South Wales. Aust. Vet. J. 75, 56-59

Venner M., Markus R. G., Strutzberg-Minder K., Nogai K., Beyerbach M., Klug E. (2008) Postpartale Immunglobulin-G-Konzentrationen im equinen Kolostrum mittels ELISA-Methode, Kolostrometrie und Refraktometrie. Berl. Münch. tierärztl. Wochenschr. 121, 66-72

Warko G., Bostedt H. (1993) Zur Entwicklung der lgG-Konzentration im Blutserum neugeborener Fohlen. Tierärztl. Prax. 21, 528-535

Erweiterte Zusammenfassung

\section{Einfluss unterschiedlicher postnataler Betreuungsme- thoden auf die Gammaglobulin-Konzentration im Serum neonater Fohlen}

Die equine Placenta ermöglicht keine nennenswerte diaplazentare Übertragung von Immunglobulinen an den Fötus. Daher weisen neugeborene Fohlen nach der Geburt nur minimale Konzentrationen an Immunglobulin $G(\mathrm{lg} G)$ im Serum auf und sind auf eine passive Übertragung von $\lg G$ via 
der Aufnahme von Kolostrum angewiesen. Grundsätzlich gilt eine $\mathrm{lg} G$-Konzentration von $\geq 8 \mathrm{~g} / \mathrm{L}$ als ausreichend $\mathrm{im}$ Fohlenserum. Wird diese Grenze unterschritten, spricht man von einem fehlerhaften passiven Transfer von Immunglobulinen (FPTI). Eine lgG-Konzentration von 4 bis $8 \mathrm{~g} / \mathrm{L}$ wird als partieller FPTI und eine lgG-Konzentration $<4 \mathrm{~g} / \mathrm{L}$ als vollständiger FPTI definiert. Fohlen mit einem FPTI gelten als besonders anfällig für Infektionskrankheiten in den ersten Lebenswochen. Wie Fohlen benötigen neugeborene Kälber eine orale Aufnahme von kolostralem lgG für den Aufbau einer protektiven humoralen Immunantwort in den ersten Lebenswochen. In zahlreichen Studien wurde dafür die postnatale Betreuung der Kälber evaluiert. Als entscheidende Faktoren um einem FPTI beim Kalb entgegenzuwirken, gelten die Menge und Qualität des Kolostrums sowie der Zeitpunkt und die Methode der Kolostrumaufnahme. Es wird geraten mindestens drei Liter Kolostrum, mit einer Kolostrumqualität von mindestens $50 \mathrm{~g} / \mathrm{L} \lg$ G, direkt nach der Geburt per Saugflasche oder Sonde zu verabreichen. Im Gegensatz dazu mangelt es an Studien, die eine optimale postnatalen Betreuung von Fohlen validieren. Nach jetzigem Kenntnisstand wird beim Fohlen eine erste Kolostrumaufnahme bis zwei Stunden nach der Geburt empfohlen, da die Resorptionsfähigkeit der neonaten Darmschleimhaut für oral aufgenommenes lgG am ersten Lebenstag progressiv fällt. Eine kolostrale lgG-Konzentration von mindesten $30 \mathrm{~g} / \mathrm{L}$ und eine Aufnahme von mindestens 1,5 Liter Kolostrum durch das Fohlen gelten als notwendig, um eine minimale humorale Immunität mit einer Serum-Konzentration von $4 \mathrm{~g} / \mathrm{L} \lg G$ zu gewährleisten. Auch ist belegt, dass die Konzentration an $\lg G$ im Fohlenserum mit 12 bis 18 Stunden einen Höchstwert erreicht. Dennoch wird empfohlen, die Serum-Konzentration mit 8 bis 12 Lebensstunden zu überprüfen, um im Falle eines FPTI noch oral Kolostrum verabreichen zu können. Es existieren jedoch kaum Studien, in denen der Einfluss einer frühen intensiven Betreuung bei der Kolostrumaufnahme, gegebenenfalls per Saugflasche, und der Einfluss einer selbständigen Kolostrumaufnahme am Euter auf den IgG-Gehalt im Fohlenserum verglichen wird. Ebenso fehlen Berichte über den Einfluss einer frühen oralen Eingabe von Kolostrum (2-8 Stunden post natum) im Vergleich zur einer späteren oralen Eingabe (8-12 Stunden post natum). Ziel der vorliegenden Studie war es deshalb, bei neonaten Fohlen, die eine unterschiedliche postnatale Betreuung erfuhren, die lgG-Konzentration im Serum innerhalb der ersten 24 Lebensstunden zu evaluieren. Dabei wurde die Konzentration an elektrophoretisch bestimmten Gammaglobulin (EGG) zur Einschätzung der lgG-Konzentration genutzt.

In die prospektive Untersuchung wurden 60 Warmblut-Fohlen (37 Hengst- und 23 Stutfohlen) eines Gestüts einbezogen. Lebensschwache Fohlen oder Fohlen von Stuten mit einem kolostralen lgG-Gehalt unter $29 \mathrm{~g} / \mathrm{L}$ wurden von der Studie ausgeschlossen. Die neugeborenen Fohlen wurden anhand einer im Vorfeld festgelegten, sich wiederholenden Reihenfolge in 2 Betreuungsgruppen eingeteilt. 40 Fohlen (Gruppe 1) erfuhren eine intensive Betreuung und erhielten, wenn nötig, Hilfe beim Aufstehen nach 1 Stunde post natum und Hilfe beim Saugen nach 2 Stunden post natum. Wenn sie nicht in der Lage waren selbständig am Euter zu saugen, erfolgte eine Eingabe von mindestens $200 \mathrm{ml}$ abgemolkenem Kolostrum der Mutterstute mittels Saugflasche. Diese Kolostrumeingabe wurde stündlich bis zum selbständigen Saufen wiederholt. Wenn sich der klinische Zustand eines Fohlens verschlechter- te, erfolgte nach acht Stunden post natum eine erneute Eingabe von mindestens 200 ml Kolostrum einer fremden Mutterstute. 20 weitere Fohlen (Gruppe 2) erhielten anfangs keinerlei Betreuung und mussten selbstständig lernen am Euter zu saugen. Wenn nach zwölf Stunden post natum kein Saufen beobachtet werden konnte oder das Fohlen eine klinischen Verschlechterung zeigte, wurden mindestens $200 \mathrm{ml}$ fremdes Kolostrum eingegeben. Die späten Kolostrumeingaben erfolgten per Saugflasche oder Nasenschlundsonde, wobei eine Nasenschlundsonde nur dann angewandt wurde, wenn das Fohlen ein Saugen an der Flasche verweigerte oder zu schwach war für solches. Bei allen Fohlen erfolgten Blutabnahmen nach 6, 8, 10, 12, 18 und 24 Lebensstunden und die Bestimmung der elektrophoretischen GammaglobulinKonzentration (EGG) mittels Serumelektrophorese.

In Gruppe 1 (Fohlen mit intensiver Betreuung) saugten 16 von 40 Fohlen in den ersten zwei Stunden post natum selbstständig am Stuteneuter, 16 von 40 Fohlen erhielten Hilfestellung um das Euter zu finden und 8 von 40 Fohlen bekamen Kolostrum per Saugflasche eingegeben. Die Daver von der Geburt bist zur ersten Kolostrumaufnahme betrug bei diesen Fohlen im Median 117 Minuten (Min.-Max.: 45-155; Tab. 1). Die Daver bis zur ersten eigenständigen Kolostrumaufnahme am Euter betrug in Gruppe 1 im Median 149 Minuten (Min.-Max.:45-484, Tab. 1). Fohlen der Gruppe 2 (ohne Betreuung bis zwölf Stunden post natum) tranken selbständig am Euter nach im Median 141 Minuten (Min.-Max.: 84-465, Tab 1). Die Daver bis zur ersten Kolostrumaufnahme war in Gruppe 1 erwartungsgemäß signifikant kürzer als in Gruppe 2 ( $p=0,002)$. Hingegen unterschied sich die Dauer von der Geburt bis zur ersten selbstständigen Kolostrumaufnahme nicht signifikant zwischen den beiden Gruppen $(p=0,549)$. Die EGG-Konzentrationen unterschieden sich nicht zwischen den beiden Betreuungsgruppen $(p=0,153$; Abb. 1), aber signifikant zwischen den Zeitpunkten $(p<0,001)$. Die niedrigste mediane EGG-Konzentration wurde in beiden Gruppen 6 Stunden post natum festgestellt (Tab. 2). Nach 10 Stunden post natum erreichten beide Gruppen eine mediane EGG-Konzentration über $8 \mathrm{~g} / \mathrm{L}$ (Tab.2). Die höchste mediane EGG-Konzentration wurde in beiden Gruppen mit zwölf Stunden post natum erfasst (Tab. 2). AnschlieBend veränderte sich die EGG-Konzentration bis 24 Stunden post natum nicht mehr signifikant (Tab. 2). Ein FPTI, definiert als eine EGG-Konzentration von <8g/L nach 24 Lebensstunden, wurde bei insgesamt 17 von 60 untersuchten Fohlen (28,3\%) beobachtet. Der Anteil an Fohlen mit einem FPTI unterschied sich nicht signifikant zwischen beiden Gruppen $(p=1,000)$. Gruppe 1 zählte 11 von 40 Fohlen und Gruppe 2 zählte 6 von 20 Fohlen mit einem FPTI.

Die vorliegende Studie bestätigte, dass neugeborene Fohlen mit durchschnittlich zweieinhalb Lebensstunden eigenständig am Stuteneuter saugen und 12 Stunden nach der Geburt eine maximale EGG-Konzentration im Serum aufweisen. Die Fohlen beider Gruppen besaßen mit 10 Stunden post natum einen EGG-Wert über $8 \mathrm{~g} / \mathrm{L}$. Demnach scheint eine Überprüfung der EGG-Konzentration zur Diagnose eines FPTI zwischen 10 bis 12 Stunden für die hier durchgeführten Methoden der postnatalen Betreuung als angemessen.

Schlüsselwörter: Fohlen, postnatale Betreuung, IgG, Gammaglobulin, Elektrophorese, passiver Transfer, Immunglobuline 